\title{
The Use of Mind Mapping In Generating Students' Idea
}

\author{
Ula Nisa El Fauziah \\ ula_nisa@ymail.com \\ STKIP Siliwangi Bandung
}

\begin{abstract}
Writing is considered as the hardest skill to be learned. Some students said that the difficult part to write is to generate ideas. They admitted that their ideas were out of focus. They could not generate and develop the ideas. To solve it, teachers surely require various teaching techniques that help students to generate ideas in writing. One of the technique is mind mapping. Based on this mentioned reasons, this study is aimed to investigate the differences between teaching writing that does not use mind mapping and the one that uses it in term of ideas. This study employed qualitative method. The data sources of this study were first grade students in one of departement in university at Bandung. The collected data were obtained by writing tests. The result of writing tests was scored by using a rubric. Based on the analysis result, it was found that there were the differences in the writing that did not use mind mapping and the one that used it in term of ideas. The writing that used mind mapping tended to be more focus. Besides, it also had deepen explanation of the topic as well as clear main idea and supporting ideas. From this finding, it can be inffered that mind mapping do really help students to generate ideas in writing. Therefore, teachers can use this technique to teach writing in the classroom.
\end{abstract}

\section{Keywords: writing, mind mapping, main idea}

\section{Introduction}

As a foreign language, English is one of the most important subjects in Indonesia. It is taught and learned as the compulsory subject in junior, senior, and university level. Moreover, there are many kindergarten school that put English as the material given for the students. At this point, its purpose is not only for encouraging students to be able to communicate with this international language, but also develop students' language skill. As stated by Zahrah in Cahyono (33: 2009), the aims of learning and teaching English is to develop students' capability in four language skills, which are speaking, listening, reading, and writing.

Regrettably, among those fours skill, writing is considered as the hardest skill to be learned. This is supported by Alwasilah (2001: 24) who says that writing is perceived as the most difficult skill to acquire by students and teach by the teachers. This difficulty might be caused by the complicated process of writing itself, in which the writers have to focus not only on grammar, vocabulary and mechanism, but also how the ideas expressed and developed. Based on 
students' discussion, many of them said that the difficult part to write was to generate the ideas. They admitted that their ideas sometimes were out of focus. They could not elaborate and generate the ideas form a particular to be written. Thus, they failed to construct a good writing either in term of fluency or coherent. This fact is in accordance with Nunan statement (cited by Fitriah in Cahyono, 2009: 66), "In term of skill, producing a coherent, fluent, and extended piece of writing is probably the most difficult things to do in language learning."

To solve this problem, teachers surely require various teaching techniques that help students to generate their ideas in writing. Mind mapping might be one of the solutions for it. Mind mapping is developed by Tony Buzan. It is simply a diagram used to represent words, ideas, or other items linked to and arranged in a free fashion around a central key words or ideas (in Cahyono, 2009:86). It usage can help the students to associate ideas, think creatively, and make connection that might not otherwise make (Buzan, 2010). Alamsyah (2009) even explains that mind mapping works well as their visual design enables students to see the relationship between ideas, and encourgae them to group certain ideas together as theyr proceed. This is supported by Huda (in Cahyono, 2009:86) who states that mind mapping can help the writer to generate, visualize, structure, and classify ideas.

The effectiveness of mind mapping to help student to generate their ideas generally have been proved by some researches. Most of the research showed that the use of mind maping can create enjoyable activity as well as facilitate students to produce an idea to write (Fitrah). Some research also show the positive influence of mind mapping to the students' writing achievement (Riswanto \& Putra, 2014).

However, there are definitely some differences between the writing that use mind mapping and the one that does not use it in term of ideas. This research is aimed to investigate those differences qualitatively.

\section{Research Methodology}

The method applied in this study is qualitative. A qualitative approach was employed due to its capability to investigate every social phenomenon that occurred in natural setting, including the use of mind mapping in writing in the classroom. As Creswell (1994) states, qualitative study is an inquiry process of understanding a social or human problem based on building a complex, holistic picture, formed with words, reporting detailed view of informant, and conducted in natural setting.

This study was conducted in English department in one of university in Bandung. The respondents of this study were first grade student who taken English Extension Program in one of university in Bandung. In their Diploma 
program, they acquired composition course on the first up to sixth semester. This course focused on how to make a good composition in the term of ideas, content, coherence, mechanism, and organization. Here, the lecture also forced them to write various compositions based on its types, such as narrative, descriptive, recount, procedural, argumentative, and so on. Thus, by their familiarity to write a good composition, the data needed for this study could be easily obtained.

In getting the data needed, this study used the writing test. At this point, the students were asked to create two compositions about holiday. The first essay did not employ mind mapping. They were free to generate idea and develop it as they wanted. In the contrary, on the second essay, they had to write an essay based on the given mind mapping.

After collecting the data needed, the students' writing is scored. Scoring system was based on writing rubric below:

Ideas

\begin{tabular}{|c|c|c|c|c|}
\hline $\begin{array}{l}\text { 1nteresting. } \\
\text { Main ideas } \\
\text { stand out } \\
\text { and are } \\
\text { developed } \\
\text { by strong } \\
\text { sup-port. } \\
\text { The writing } \\
\text { is characteri- } \\
\text { zed by: } \\
\text { - Main idea } \\
\text { (s) that } \\
\text { stand out. } \\
\text { - Supportin } \\
\text { g idea (s) } \\
\text { is relevant } \\
\text { to the } \\
\text { main idea. } \\
\text { - Depth } \\
\text { explanatio } \\
\text { n or } \\
\text { explora- } \\
\text { tion of the } \\
\text { topic; the } \\
\text { writing } \\
\text { shares }\end{array}$ & $\begin{array}{l}\text { 4. The } \\
\text { writing is } \\
\text { clear, } \\
\text { focused and } \\
\text { interesting. } \\
\text { Main ideas } \\
\text { stand out } \\
\text { and are } \\
\text { developed } \\
\text { by limit or } \\
\text { general } \\
\text { supporting. } \\
\text { The writing } \\
\text { is } \\
\text { characterize } \\
\text { d by: } \\
\text { - Main idea } \\
\text { (s) that } \\
\text { stand out. } \\
\text { - Supportin } \\
\text { g idea (s) } \\
\text { is } \\
\text { relevant, } \\
\text { but may } \\
\text { be over } \\
\text { general or } \\
\text { limited. } \\
\text { - A topic is } \\
\text { explained; } \\
\text { experienc }\end{array}$ & $\begin{array}{l}\text { 3. The writing } \\
\text { is clear and } \\
\text { focused. The } \\
\text { reader can } \\
\text { easily under- } \\
\text { stand the main } \\
\text { ideas. Support } \\
\text { is present, } \\
\text { although some } \\
\text { of may be } \\
\text { limited/general } \\
\text { or irrelevant. } \\
\text { The writing is } \\
\text { characterized } \\
\text { by: } \\
\text { - Clear main } \\
\text { idea(s). } \\
\text { - Some of } \\
\text { supporting } \\
\text { idea (s) may } \\
\text { be relevant } \\
\text { but } \\
\text { limited/gene } \\
\text { ral; and } \\
\text { some of } \\
\text { them may be } \\
\text { irrelevant. } \\
\text { - The } \\
\text { explanation } \\
\text { of the topic }\end{array}$ & $\begin{array}{l}\text { 2. The } \\
\text { writing is } \\
\text { unclear and } \\
\text { quite focus. } \\
\text { Main ideas } \\
\text { can be iden- } \\
\text { tified. The } \\
\text { developmen } \\
\text { t supporting } \\
\text { idea is at- } \\
\text { tempted but } \\
\text { minimal or } \\
\text { irrelevant. } \\
\text { The writing } \\
\text { is } \\
\text { characterize } \\
\text { d by: } \\
\text { - Main idea } \\
\text { (s) is not } \\
\text { stated } \\
\text { clearly. } \\
\text { - Irrelevant } \\
\text { details } \\
\text { - Limited } \\
\text { explanatio } \\
\text { n of the } \\
\text { topic. }\end{array}$ & $\begin{array}{l}\text { 1. The } \\
\text { writing } \\
\text { lacks a } \\
\text { central idea } \\
\text { The writing } \\
\text { is characte- } \\
\text { rized by: } \\
\text { - Ideas that } \\
\text { is } \\
\text { extremely } \\
\text { limited or } \\
\text { simply } \\
\text { unclear. } \\
\text { - Attempts } \\
\text { at } \\
\text { developm } \\
\text { ent that } \\
\text { are } \\
\text { minimal } \\
\text { or non- } \\
\text { existent. } \\
\text { - The pape } \\
\text { is too } \\
\text { short to } \\
\text { demonstr } \\
\text { ate the } \\
\text { developm } \\
\text { ent of an } \\
\text { idea. }\end{array}$ \\
\hline
\end{tabular}




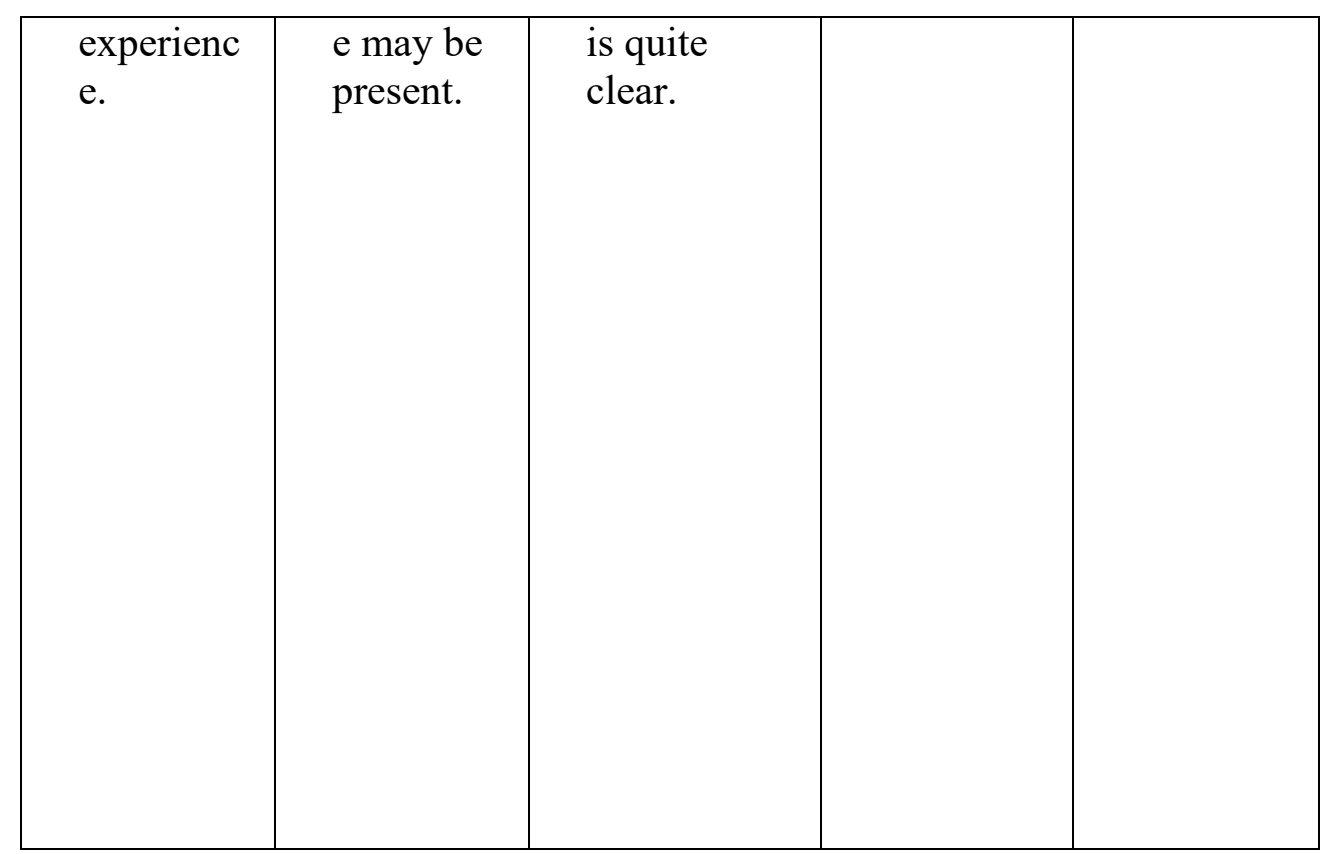

The above rubric refers to the content of writing that deals with the topic of as well as its main and supporting ideas. As Brown (2001) said content refers to thesis statement, related ideas, development of ideas through personal experience, illustrations, fact, and opinion.

\section{Result and Discussion}

As it is stated previously, mind mapping is a diagram used to represent word, ideas, or item linked to and arranged in a free fashion around a central key word or ideas. This kind of technique is effective to help to generate, develop, and classify the ideas in writing. However, out of this effectiveness, there is definitely some differences between the one that does not use mind mapping and the one that use it in term of ideas. The following data attempts to investigate it:

\section{First Respondent}

The data below is written by the first respondent. There is no title of this writing. However, as it can be seen on the first sentence of the first paragraph, the writer wants to share her experience in Bali to the reader. 


\section{Non Mind Mapping}

I and my family spent our earlier holiday in Bali. We didn't take the airplane to go there. We took the car since we planned to visit several temples and ancient mosques around the island of Java though our first destination was Bali. We left our city on Sunday at 9 am and took a rest at a hotel in central Java. The next day we continued our journey and finally arrived at Bali at $11 \mathrm{pm}$.

We visited Kuta beach and national bird park. We spent two days in Bali and then returned to our city. On the way home, we took some rest in Surabaya. I have some friends in this city so I decided to meet them. The next day, we continued our journey and visited Prambanan temple and then Borobudur temple where we bought some gifts. We also prayed at Sunan Kudus and Sunan Ampel mosques along the journey. Finally we arrived at Bandung and took some rest.

It was a nice holiday. I feel like I was touring around the islands of Java and Bali.

On the introductory paragraph, the writer explains general information of her holiday, such as time, with whom she gone, and the accommodation she used. In term of accommodation, she attempts to put some detail by explaining of why she chooses a car rather than an airplane. Unfortunately, she does not explain of why she chooses Bali as place she wants to spend her holiday. As Thomas (2001) stated, orientation or introductory paragraph of recount should contain the information of when, where, why, and how.

On the second paragraph, the writer does not declare her focus. Her idea jumps from one to another. As it can be seen above, the main idea stays on the first paragraph, which is "we visited Kuta Beach and National Park". However, the second and remain paragraphs do not support it. She prefers to explain how many days that she spent in Bali than tell what she got or experienced in both places as well as her feeling. Moreover, she also informs to the reader of places she visited back from Bali in Surabaya on the same paragraph. It shows irrelevant idea to support the main one. As a result, there is no area that becomes a center that she is interested in. Then, since there is no further explanation about places she visited, her writing seem to be a report than retelling an experience.

On the last paragraph, the writer attempts to express her feeling of her holiday by saying, "it was a nice holiday. I felt like I was touring around the island of Java and Bali. The last sentence for certain supports the previous one. However, as a conclusion of the whole experience stated in her written form, the reader cannot get a depiction of why her experience is nice. Thus, by the above consideration, this writing stays on the first level in the rubric. 


\section{Mind Mapping}

It's hot on summer. Therefore, I and my friends decided to spend our holiday in the mountain range in Puncak Bogor where the air is cool and fresh. We took a bus to go to puncak in the morning at about $8 \mathrm{am}$ and arrived at about $10 \mathrm{am}$. We rent a cottage near the tea fields where the view is really nice. Since the cottage is near the At Ta'awun mosque, we conducted the prayer there.

We trekked around the tea fields and had a conversation with some farmers who worked at the fields. We learned how to pick the tea leaves and found that it was not an easy task to pick tea leaves as much as possible in a short time. The farmers then gave us big pockets of dried tea leaves. We thank them and brew the tea leaves at the cottage. It was really relaxing when we sipped a cup of hot tea while looking around the green view.

The writer improvement shows on the above writing that uses mind mapping. On the introductory paragraph, for instance, she clearly tells the background of her experience. She explains why she chooses mountain range in Puncak Bogor to spend her holiday, when she goes, with whom she goes there, and the used accommodation.

The improvement is also demonstrated on the second paragraph. Her idea becomes more focus. As it is showed, the main idea stays in the first sentence, "we trekked around the tea field and had a conversation with tea farmer". To support it, she explains what she is done latter. Then, she attempts to share her feeling to the reader by saying "it was not an easy task" and "it was really relaxing when sipped a cup of hot tea while looking around the green view". Unfortunately, on the second sentence, she does not explain how to pick the tea leaves. Whereas, she can explain it in order to make the ideas more develop.

Since the writing becomes more focus, a significant point of interest in this writing is also emerged. Thus, based on the rubric, it stays on the forth level.

\section{Second Respondent}

The two data served below is written by different respondent. From the title, it can be seen that the writer wants to retell his experience in spending holiday in Bogor Botanical Garden. 


\section{Non Mind Mapping \\ My Holiday at Botanical Garden}

Last holiday, my friends and I went to Bogor Botanical Garden. It took about four hours to go there by bus from Bandung. We were enjoying the view along the journey. While enjoying the view outside, we were having fun and laughing inside the bus most of the time. It was noisy but interesting.

Along the trip, my friends who are in relationship talked about the myth in Bogor Botanical Garden. It says that the couple who comes to that place will soon break up. At first, some friends worried about it, but they just ignored it afterwards.

When arrived at Bogor Botanical Garden, nothing we did but enjoying the beautiful flowers and plants in the garden. We were moving around and taking pictures in many spots. It was wonderful

The most interesting moment was when we found the huge flower, named Rafflesia Arnoldy. The diameter is about 1 meter long and the stalk is about 2 meters high. The smell is so bad that we must close our nose when approaching the flower. However, we took some pictures next to the flower.

Besides Bogor Botanical Garden, we also visited some interesting places in Bogor, such as the Bogor Palace, and some historical buildings. Time flew and we had to go home. Anyway, it was a beautiful holiday.

On introductory paragraph, the writer tells about informational background of his vacation, such as with where he goes, with whom he goes, the used accomodation, and how long to get the destination. At this point, he also adds some details that explain what he does along the journey and his feeling. As an introductory paragraph, it is quite developed to explain the information of his experience.

In telling the series of event that he experienced, the writer's main idea can be identified although its supporting ideas is limited. On the second paragraph, for example, the main idea stands on the first sentence "...talked about the myth in Bogor Botanical Garden". He then supports it by mentioning what kind of myth. It is then followed by explaining his friend feeling. Whereas, in this case, he can explores his supporting idea by giving the description of his friends action that show their discomfort to the myth up to they have to ignore it. Thus, by doing so, his ideas might be more developed.

The limitation of supporting idea also occurs on the third paragraph. In this paragraph, the main ideas stays on the first sentence "nothing we did but enjoying the beautiful flowers and plant...". However, on the second sentence, he prefers to tell his activity of moving around and taking some pictures than explain 
what beautiful flower he saw. In this case, the supporting idea basically still relevant to the main topic, but it is just not quiet developed. It is supported by the length of paragraph which only consists of two sentences.

Fortunately, the problem mentioned above does not present on the fourth paragraph. The main idea that lies on the first sentence, " ...found a huge flower, named Rafflesia Arnoldi", is supported by good supporting ideas. Here, he explains about the physical performance of Raflesia Arnoldi that has big diameter and stalk. He also tells about his feeling when he saw it. Thus, here, the writer shows his interested area of his experience as well as draw reader feeling into his experience.

Regrettably on the last paragraph, it shows unclear ideas. In this case, there are two events on the same paragraph. On the first sentence, he attempts to inform some interesting places he visited in Bogor. However, in the second sentence, he tells about her feeling of his holiday instead of explain it further. Therefore, the irrelevant ideas are showed. Basically, the writer can combine these two events in one sentence. But, it is better for him to utter the statement that supports his main idea. Thus, the story will be more flow and fluent.

Based form all the above consideration, such as informational background of the experience, presentation of area he is interested in, conclusion of her whole feeling of his experience, limitation of supporting idea, and irrelevant supporting idea, this writing stays on the third level based on the rubric.

\begin{tabular}{l} 
Mind Mapping \\
\hline My Holiday at Botanical Garden \\
Last month, my friends and I spent our holiday visiting some \\
historical buildings in Bogor. The places to visit were Bogor \\
Botanical Garden, Bogor Palace, and some museums. Besides, we \\
also came to some shopping centers to buy merchandise. \\
We went to Bogor from Bandung in the afternoon when the \\
weather was sunny. It took about four hours to go there by bus. \\
However, we were enjoying the trip while seeing the beautiful \\
view outside. The atmosphere became so cheerful when we made \\
fun of each other along the trip. \\
While enjoying the view along the trip, we talked about the \\
myth in Bogor Botanical Garden. It says that the couple will soon \\
desperate if they visit the place. At first, my friends who are in \\
relationship worried about this. However, they just ignored it and \\
turned to another topic. \\
When arrived in Bogor, we came to a cottage to spend the \\
night before we went to some places tomorrow morning. The \\
cottage was located in a mountain area. It was so cold that we \\
must wear the jacket all the time. \\
The following morning, we went to Bogor Botanical Garden.
\end{tabular}




\begin{abstract}
We moved around the garden and take some pictures. Some of us were making fun of each other when coming to the hanging bridge, the mythical place in the garden.

The most interesting moment was when we found the huge flower, named Rafflesia Arnoldy. The diameter is about 1 meter long and the stalk is about 2 meters high. The smell is so bad that we must close our nose when approaching the flower. However, we also took some pictures next to the flower.

After visiting Bogor Botanical Garden, we went to other historical buildings. We also came to shopping centers along the countryside to buy merchandise.

It was a beautiful holiday. Hopefully, I could come to Bogor again and visited another interseting place.
\end{abstract}

Compared to the discussed one, here, the writer attempts to develop his idea. On the introductory paragraph, the writer adds detail information of the place he visited. Regrettably, he just mentioned it without giving detail information about it, such as of why he chooses the places to spend his holiday. Here, the limitation of supporting idea still emerges.

On the second paragraph, he attempts to add the information of what he is first done in Bogor. In that case, the main idea is "spend the night in cottages". He supports it by explaining the location of the cottage as well as its situation. At this point, idea is developed.

Moreover, on the third one, he informs her experience in historical building as well as merchandise shop. Similar with the first problem, the writer just mentioned it as report than try to add some explanations about it.

Meanwhile, on the last paragraph, it seems that he adds the information of why he should go home before come up to the conclusion of his experience. The good one here, the writer states his next plan if he comes to Bogor again. As Thomas (2001) stated, re-orientation in recount is an ending statement often used to reflect on or comment on the events, recounted, or to predict

From the explanation above, it can be inferred that the writer's idea on the second writing shows significant improvement. He attempts to develop his idea by set the event in a right order, from the information of place she visited up to conclusion of his feeling about his holiday. However, for the development of idea in each paragraph, it does not show any progress. The explanation is still limited. Thus, on the rubric, it still reaches level 4. 


\section{Third Respondent}

From the title, the following data notifies the reader of the writer experience in doing rafting, a challenging recreational outdoor activity using an inflatable raft to navigate a river or other bodies of water.

On the first paragraph, the writer does not only explains the basic informational background of his story (how, when, where, who, and why), but also justifies of why he wants to go vocation. As it can be seen on the first sentence, he says "Holiday is a necessity for everyone, including me, to get away from daily routine". It seems to become the main point of that paragraph. He then supports it by an idea to go vacation with his friends, which is followed by some actions to implement his idea to go rafting. At this point, his supporting idea is still limited since there is no explanation of what kind of research he did, why he did it, etc.

On the second one, the restrictiveness of supporting ideas is also shown. The main idea is "starts our journey". He supports it with the explanation of his first stop to buy some foods for the journey and the depiction of his feeling toward the view. Unfortunately, he does not give to many descriptions of how the scenery looks like and what make it differents with the other city.

On the other hand, on the third paragraph, both mind idea and supporting idea cannot be identified. There are two series of event. First, he does not familiar with the place he visited, so that he asks the organizer to pick him up. Second one is his rafting activity. Basically, the supporting idea on the second one is quit developed. He shows his feeling "I feel very excited" along with the briefing and practice he did. Unfortunately, since there are two combination of event, it becomes unclear. It is better for him to vividly explain two events into two paragraphs.

On the last paragraph, the writer states his activity before going home. Similar with the first and second one, his suporting idea is also restricted. He does not explain clearly what special food in the area he visited. He prefers to jump the idea into to his feeling.

\begin{tabular}{|l|}
\hline Non Mind Mapping \\
\hline \multicolumn{1}{|c|}{ Rafting } \\
Holiday is a necessity for everyone, including me, to get away \\
from daily routines. Last month, when I'm so tired with my daily \\
routines my friends came up with an idea to have a day off and go \\
to Pangalengan to do rafting. I became extremely interesting with \\
his idea because I never do rafting before. After doing some \\
research, I finally found on outbound organizer to accommodate \\
our desires to do rafting. After everything settle, we agree to use \\
my friend's car and meet at 9 AM in Margahayu. \\
\hline
\end{tabular}


After everyone gathered, we start our journey to Pangalengan On our way to Pangalengan we made our first stop at a minimarket to buy something to eat on our way to Pangalengan. I very like the scenery on the mountain area like Pangalengan, because it's very different from what I see in the city. To see trees on the side off the road is very refreshing.

When we entered the city, my friends called the organizer so they can pick us up because we did not know the place. After we meet with the organizer, they told us to follow them because they used a motorcycle.

When we set our foot at the rafting place, I feel very excited. After changing clothes we had a small briefing and a little practice. We learn how to paddle and how to react when we doing rafting. Finally the time has come to do the real rafting. During rafting I had so much fun and it really test my adrenalines. The rafting itself only took about an hour but me and my friends really exhausted.

After getting wet from rafting, we took a shower before going home. On our way back, we buy some local specialties. It was so much fun to have a little time to get away from daily routines because it can make us refresh our mind and not feel bored with work again.

Overall, this writing is focus. In other word, the writer's idea do not jump from one to another. He is consistent to explain his vocation in Pangalengan. Moreover as a recount, it has gained its purposes to retell past experience as well as to share feeling and thought. Regrettably, since there is the limitation in supporting paragraph as well and supporting idea, it stays on the 4 level.

Mind Mapping
Rafting
On November 2010, my friend and I had a plan to have a
vacation. He and I feel very tired with our daily routines so we
could use a holiday. Unfortunately, he and I only have one day
off, so we can go too far from our city. After searching a good
place to spend our holiday, my friend and I decided to go to
Pangalengan. My friend told me that we can do rafting in
Pangalengan and ask me to find a good outbound organizer in
Pangelangan. So I browse the internet to find a good and
affordable outbound organizer. After found one, I discussed the
price we have to pay with my friends and he agreed with it. We
have to pay about Rp 185.000 for about an hour of rafting, local
transport, lunch, and snack.
After everything settled, we contacted our other friends to
come with us too and have some fun. Unfortunately some of them
were busy doing other things, so there only five of us and my
friend parents. They decided to come along with us because they


feel bored stay at home all day long.

On the agreed day, exactly November 21, my friend picked me up at my house. He picked me up 8 AM. Before we went to Pangalengan, we gathered first at my friend house in Margahayu. We arrived at Margahayu at 9 AM. We had a little conversation about which route we should take to avoid traffic because. After everything packed and ready, we began our journey to Pangalengan. However, as we predicted before, the traffic was very busy that day and it made us spend a lot of time on our way to Pangalengan. We spend nearly three hours on the road.

In Pangelangan, we called the organizer. We asked them to pic $\mathrm{k}$ us up at the local clinic. It is due to we did not know where the rafting spot is. It is a new place for us to be visited. Fifthen minute latter they arrived. Since they used a motorcycle, we followed them at back.

It is not more than ten minute, we arrived at the place. We took a little break and enjoy the mountain view. We can see a lake and many trees in sides of the road. It was very refreshing. After take a little break, we had a briefing about the equipment we will use during rafting and safety procedures with the instructor.

After all that briefing finished, we went to the rafting spot. I feel very excited because this is my first time. During rafting we can also see a nice view while paddling. We move from side to side because it was very bumpy. Water splashes in front of our faces, adrenalines rises, but it was so much fun and we keep laughing. Before we reach the final destination, the instructor told us that the raft is leaking. We all terrified to hear that. The instructor told us to move to the right side of the raft. But he suddenly fliffed the raft and made all of us jump into the river. $\mathrm{He}$ just laugh see we all panicked. He said that it was a joke and the raft is fine, not leaking at all, so we all laughing and glad to hear that. At the final destination there's already a car prepared to pick us up and take us back to the starting spot.

After doing a rafting, we were very tired. We took a rest for a while. We ate food to charge our body. It is about ten minute latter, we decided to take a bath and change our wet clothes with dry ones. The water is very cold. Many of us was shiver at that time.

Since the rain started to pour down, we decided to go home. We hit the pedal and made our way back home.

The above writing shows the improvement. There is the main and supporting idea in each paragraph. On the first paragraph, for instance, the main idea is "...had plan to go vacation". The writer support it by depth explanation of the reason we want to go vacation, destination he want to visited, activity that he want to do, and facilitate he got if he use organizer. 
It is continued to the next paragraph. On the second paragraph, the main idea stands on "..contacted our friend". He relates it with the reason of why he called his friends and the information of the people that want to join vacation with him.

On the sixth paragraph, the writer attempts to show his feeling by saying "I feel very excited because this is my first time". This is in line with Glasswell, Parr, and Akman (2001) statement, in which personal recount often includes reflections on the writer's feelings.

Since there are clear main ideas as well as strong supporting idea, the explanation of the topic become in-depth. The reader really gets depiction of what the writer experienced at that time. Then, based on this consideration, this writing stays on the fifth level in the rubric.

Based on the findings above, it can be inferred that mind maping definitely help the students to generate and develop the ideas. This supports Busthomi's statement (in Cahyono, 2009:75). He states that mind mapping gives advantages for the writer to stimulate ideas, to build a list of issues, to identify relationship between them, and to prioritize what will be important to write about. This is also in line with Hunan (quoted by Huda in Cahyono, 2009:86) who states that mind mapping can help the writer to generate, visualize, structure, and classify ideas.

\section{Conclusion}

Based on the finding and discussion in the last chapter, the result of the study can be concluded as follow:

There are the differences between the writing that does not use mind mapping and the one that use it in term of idea. On the first one, the writing tends to be unfocused and unclear. Besides, the mind idea sometimes cannot be indentified and supporting ideas are limited and irrelevant. Meanwhile, on the second one, the writing tends to be more focus. The writers attempt to explain the topics deepen. Moreover, there is the clarity of main and supporting idea, though some of the supporting ideas are still limited.

From the above conclusion, it is expected that teachers can use mind mapping to teach writing in the classroom. In this case, they can give their students mind mapping that they made, before they asked them to make it by their own. 


\section{References}

Alwasilah, Chaedar. (2009). Pokoknya Kualitatif: Dasar-dasar Merancang dan Melakukan Penelitian Kualitatif. Jakarta: Pustaka Jaya.

Alwasilah, Chaedar. (2009). Language, Culture, and Education: A Portrait of Cotemporary Indonesia. Bandung: Andira.

Brown, H. Doughlas. (2001). Teaching by Principle: An Interactive Approach to Language Pendaogy. New York: A Pearson Education Company.

Boswel.1995. Available at www.mindmap.co.au/advantage

Buzan, Tony (2004). How to Mind Map, Mind Map untuk Meningkatkan Kreativitas. Jakarta: Gramedia Pustaka Utama

Byrne, Don. (1979). Teaching Writing Skill. Longman Handbook for Language Teacher. Singapore: Longman Group Ltd. England.

Cahyono, Yudi, B. (2009). Techique in Teaching EFL Writing. Malang: State University of alang Press.

Creswell, J. W. 1994. Research Design: Qualitative \& Quantitative Approaches. New Delhi : Sage Publications.

Glasswell, Parr, Aikaman. (2001). Development of the asTTle Writing Assessment Rubrics for Scoring Extended Writing Tasks.

Hudgson, Anne. (2007). Recount. Available at http://skillworkshop.org.

Indriyani, L. 2007. The Use of Language by Bandung Radio Broadacsters: A study on Register. Unpublished research paper. Indonesia University of Education, Indonesia.

Iscaac, S. \& Michael. W.B. (1981). Planning Research Studies. San Diego: EdiTs

Jumika. (2009). Improving Students Ability in Writing Recount Paragraphs Through Webbing Techniques: An Experimental Study. Unpublished research paper. Indonesia University of Education, Indonesia.

Kusumaningsih, L. 2009. Unpublished research paper. Indonesia University of Education.

Stafii, M. (2001), Aspect of Writing: A case Stusy of Intricacies in Writing Encountered by The Second Year Students at The English Education Departement of State Institute For Islamic Departement. Unpublished research paper. Indonesia University of Education, Indonesia. 
Strauss, Anselm \& Corbin, Juliet. (1990). Basic of Qualitative Reserach: Grounded Theory Procedure and Technique. Newburry Park, C.A: Sage.

Syamsudin \& Damaianti, Vismaia. (2006). Metode Penelitian Bahasa. Bandung: Remaja Rosdakarya.

Thomas(2006). Available at http://english-text.blogspot.com/ 